\title{
ANALISIS HYBRID CONTRACT PADA TAKE OVER PEMBIAYAAN HUNIAN SYARIAH DARI BANK KONVENSIONAL KE BANK SYARIAH DALAM PERSPEKTIF HUKUM EKONOMI ISLAM
}

\author{
Muhammad Fuad Mas'ud \\ Fuadfaqot12@gmail.com \\ Pascasarjana Hukum Ekonomi Syariah \\ UIN Sunan Gunung Djati Bandung
}

\begin{abstract}
ABSTRAK
Kebutuhan akan rumah sebagai tempat tinggal atau hunian terus meningkat seiring dengan bertambahnya penduduk. Harga rumah yang begitu tinggi menyebabkan tidak semua orang mampu membelinya secara tunai. Pembiayaan hunian yang ditawarkan oleh berbagai bank menjadi jalan keluar bagi orang-orang yang menginginkan sebuah hunian dengan cara mencicil ke bank. Bank syariah pun mulai mengembangkan fasilitasnya hingga kepada pembiayaan hunian syariah sampai dengan pengalihan (take over) pembiayaan hunian syariah dari bank konvensional ke bank syariah. Pada pembiayaan hunian ini, terjadi dua akad yaitu bai' dan murabahah. Sedangkan pada Hukum Islam dijelaskan bahwa Nabi Muhammad SAW melarang dua transaksi jual beli dalam sekali transaksi.. Termasuk di dalamnya proses take over pembiayaan hunian syariah yang mengandung multi akad. Proses take over yang dilakukan oleh bank syariah ke bank konvensional dengan sistem syirkah al-milk, lalu memberikan produk pembiayaan hunian syariah kepada nasabah dengan akad ba'i murabahah tidak dapat dimasukkan ke dalam hybrid contracts yang dilarang dalam perspektif Hukum Islam.
\end{abstract}

Kata Kunci: Hybrid Contract, Take Over, Bank Syariah,dan Bank Konvensional 


\section{PENDAHULUAN}

Islam hadir di tengah-tengah umat sebagai pedoman hidup dan jalan hidup yang bisa menjawab dan memberikan berbagai macam solusi dari setiap sendi kehidupan manusia. Lima nilai universal ajaran islam yang diformulasikan dalam maqosid al syari'ah, yaitu hifdzul din, hifdzud nafs, hifdzul mal, hifdzul nasl, dan hifdzul ' $i r d h^{1}$ merupakan pondasi utama dan barometer inti formulasi hukum setiap aktivitas manusia. Semua aktivitas dan kegiatan manusia wajib diukur dengan aturan dan regulasi yang sejalan dengan nafas maqosid syari'ah, karena aktivitas manusia harus berbasis kemaslahatan, sedangkan kemaslahatan ada dalam aturan syariat. Izudin bin abdi al salam mengatakan, al syari'atu kulluha masolih wa dafu'l mafasid (syariat itu semuanya kemaslahatan dan menolak mafsadah) ${ }^{2}$

Paradigma usuliyyun dalam konsep qiyas menyatakan, al nusush mahdudah wal masail mutajaddidah ${ }^{3}$ (teks agama itu terbatas, sedangkan permaslahan manusia terus berkembang). Paradigma usuliyyin tentang teori limit nash merupakan pintu dan peluang untuk mengembangkan

1 - Al Syatibi, Al Muwfaqot, ....

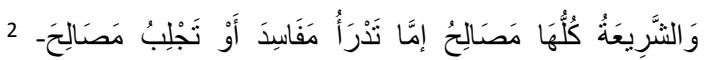
Izzudin bin Abdi Al Salam, Qowaid Al Ahkam, Maktabat al kulliyat al azhariyah, Kairo, 1991, hal. 11/1

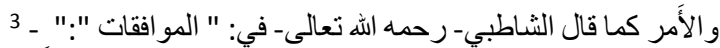

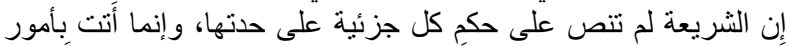

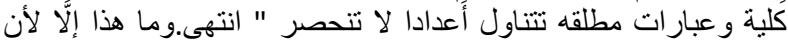

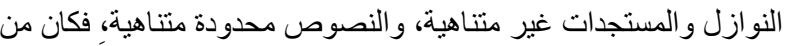

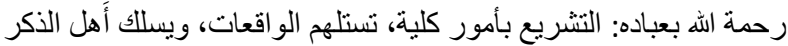

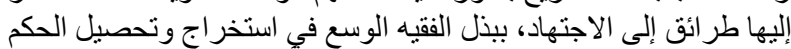

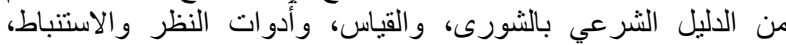
Bakar bin Abdullah, Al Madkhol Al Mufasshol Li Madzhab Imam Ahmad, Darul 'Ashimah, Jeddah, $1417 \mathrm{H}$, hal. 95 ijtihad dan berinovasi dalam hal baru yang tidak ditemukan hukumnya dalam al quran dan al hadist secara eksplisit dengan berpegang kepada prinsip nilainilai maqosid syari'ah.

Formulasi hukum yang dirumuskan oleh para fuqoha dalam kitab-kitab fikih merupakan hasil inovasi dan produk ijtihad mereka dalam menafsiri kandungn hukum al quran dan al hadist. Fikih adalah produk ijtihad yang dibangun oleh spekulasi (dzon) dan inovasi (al ibtiakri) yang dominan dalam akal mujtahid, sehingga tidak menutup celah untuk salah. Konsep ijtihad maqosidi mendominasi dalam proses pembentukan hukum parsial yang ada dalam kitab fikih, dimana penafsiran mereka terhadap teks agama disinergikan dengan prinsip universal agama yang tertuang dalam lima prinsip syariah (al maqosid al khomsah) tersebut.

Salah satu inovasi dalam lembaga keuangan syariah yang merupakan bagian dari penegmebangan produk hukum fikih adalah strategi pemasaran yang dikembangkan oleh bank-bank saat ini adalah dengan pengalihan (take over) pembiayaan hunian syariah. Take over pembiayaan hunian adalah pemindahan fasilitas pembiayaan yang berjalan disuatu bank ke pembiayaan bank lain. Pengambilalihan ini hanya untuk sisa pokok pinjaman nasabah dari bank pemberi pembiayaan pertama, yang dilanjutkan dengan mencicil sisa pokok pinjaman ke bank yang mengambilalih pembiayaannya. Take over dapat dilakukan sesama bank konvensional atau sesama bank 
syariah, maupun dari bank konvensional ke bank syariah ataupun sebaliknya.

Salah satucontoh pembiayaan hunian syariah yang digunakan oleh Bank Syariah Mandiri (BSM) bernama Pembiayaan Griya Bank Syariah Mandiri. Pembiayaan Griya BSM adalah pembiayaan jangka pendek, menengah, atau panjang untuk membiayai pembelian rumah tinggal, baik baru maupun bekas, di lingkungan developer dengan sistem murabahah ${ }^{4}$. Akad bai' al murabahah adalah jual beli barang pada harga asal dengan tambahan keuntungan yang disepakati. Dalam bai' al murabahah penjual harus memberitahu harga produk yang ia beli dan menentukan suatu tingkat keuntungan sebagai tambahannya ${ }^{5}$.

Fakta menjelaskan bahwa dalam hal take over pembiayaan hunian syariah dari bank awal ke bank syariah telah terjadi dua akad dalam satu transaksi atau lebih dikenal dengan istilah hybrid contract atau multiakad. Pada pembiayaan hunian ini, terjadi dua akad yaitu bai' dan murabahah. Sedangkan pada Hukum Islam dijelaskan bahwa Nabi Muhammad SAW melarang dua transaksi jual beli dalam sekali transaksi.Sebuah riwayat menyebutkan bahwa Nabi Muhammad SAW melarang transaksi jual beli dan dua syarat dalam satu jual beli.

4 - Bank Syariah Mandiri, Pembiayaan Griya BSM, https://www.syariahmandiri.co.id/category/consumerbanking/pembiayaan-konsumer/pembiayaan-griyabsm/ diakses pada tanggal 13 Desember 2019, pukul 23.16 WIB

5 - Muhammad Syafi'i, Bank Syariah Suatu Pengenalan Umum (Bogor: Tazkia Institute, 2000), 145
Diriwayatkan pula dari 'Amr bin Syu'aib, dari bapaknya dari kakeknya bahwa Nabi SAW bersabda, yang artinya: “Tidak boleh terjadi pinjaman bersamaan jual beli, dua syarat dalam satu jual beli, keuntungan tanpa ada jaminan, dan menjual sesuatu yang kamu tidak miliki." Sabda Nabi Muhammad SAW tersebut, ditafsirkan oleh para ahli fiqih sebagai dua transaksi jual beli dalam satu jual beli. Kemudian saat ini dikenal dengan istilah hybrid contract. Hybrid contract merupakan akad ganda (rangkap) ${ }^{6}$.

Terdapat perbedaan pandangan antara para ahli fiqih, ada yang berpendapat bahwa melakukan hybrid contract diharamkan, tetapi ada pula yang berpendapat hanya beberapa hybrid contract saja yang haram. Berdasarkan uraian tersebut di atas, permasalah yang terjadi adalah bagaimana implementasi hybrid contract dalam take over pembiayaan hunian syariah dari perbankan konvensional ke perbankan syariah pada praktiknya menurut persepktif Hukum Islam.

\section{Hybrid Contract dalam Perspektif Hukum Ekonomi Islam}

Di era transaksi keuangan modern yang semakin kompleks, dibutuhkan design kontrak akad dalam bentuk kombinasi beberapa akad yang disebut dengan hybrid contract (multiakad), atau biasa disebut al-ukud al-murakkabah. Bentuk akad tunggal sudah tidak mampu meresponi transaksi keuangan kontemporer. Kombinasi akad zaman sekarang

6 - Ascarya, Akad \& Produk Bank Syariah (Jakarta: Raja Grafindo Persada, 2007), 35. 
adalah sebuah keniscayaan, akad tunggal sudah tidak mampu lagi meresponi kasus-kasus dan problem keuangan kontemporer. Untuk itu, perbankan syariah harus memperbaiki diri dalam peningkatan kualitas SDM-nya dengan melaksanakan training dan workshop intensif mengenai inovasi produk ${ }^{7}$.

Buku-buku teks fikih muamalah kontemporer menyebut istilah hybrid contracts dengan istilah yang beragam, yaitu al-ukud-murakkabah, al-ukud al mujtami'ah, adapula yang menggunakan istilah al-ukud almutajanisah. Menurut istilah fikih, kata hybrid contracts merupakan terjemahan dari kata Arab yaitu al'uqudal-murakkabah yang berarti akad ganda (rangkap), akad yang bergabung, akad yang berhimpun, akad yang berkombinasi. Al-'uqud al murakkabah terdiri dari dua kata al-'uqud (bentuk jamak dari 'aqd) dan al-murakkabah. Kata 'aqd secara etimologi artinya mengikat, menyambung, atau menghubungkan (arrabt).

Menurut Syamsul Anwar akad (perjanjian) adalah pertemuan ijab dan kabul sebagai pernyataan kehendak dua pihak atau lebih untuk melahirkan suatu akibat hukum pada objeknya ${ }^{8}$. Kata al-murakkabah (murakkab) secara etimologi berarti al-jam'u (mashdar), yang berarti pengumpulan atau penghimpunan ${ }^{9}$. Kata murakkab sendiri berasal dari kata

7 Agustianto Mingka, Op. Cit., hlm. 91.

${ }^{8}$ Syamsul Anwar, Hukum Perjanjian Syariah "Studi Tentang Teori Akad Dalam Fikih Muamalat" (Jakarta: Raja Grafindo Persada,2007), 68.

${ }^{9}$ Munawwir, Kamus Al-Munawwir Arab-Indonesia (Surabaya: Pustaka Progresif, 1997), 209. "rakkabayurakkibu-tarkiban" yang mengandung arti meletakkan sesuatu pada sesuatu yang lain sehingga tersusun dengan baik, ada yang di atas dan yang di bawah ${ }^{10}$. Sedangkan murakkab menurut pengertian para ulama fikih (dalam konteks akad) ialah himpunan beberapa akad sehingga disebut dengan satu nama akad. Dalam teorinya terdapat beberapa penggabungan akad yang dilarang.

Dalam hadist, Nabi Muhammad SAW secara jelas menyatakan dua bentuk hybrid contract yang dilarang, yaitu hybrid contracts dalam jual beli (bay') dan pinjaman serta dua akad jual beli dalam satu akad jual beli dan dua akad dalam satu transaksi. Dalam sebuah hadist "Dari Abu Hurairah, Rasulullah melarang jual beli dan pinjaman". (HR. Ahmad), yang artinya salah satu yang akad yang dilarang yaitu menggabungkan akad bay' (jual beli) dan salaf (pinjaman). Sebagai contoh Ali meminjamkan (qardh) sebesar 1000dirham, lalu dikaitkan dengan penjualan barang yang bernilai 900dirham, tetapi harga penjualan itu tetap harga 1000dirham. Seolah-olah Ali memberi pinjaman 1000 dirham dengan akad qardh, dan menjual barang seharga 900 dirham, agar mendapatkan margin 1000 dirham. Disini Ali memperoleh kelebihan 100dirham.

Ibn Qayyin berpendapat bahwa Nabi Muhammad melarang hybrid contracts antara akad salaf (memberi pinjaman/qardh) dan jual beli, untuk menghadiri terjerumus kepada riba yang diharamkan.

\footnotetext{
10 - Agustianto Mingka, Op. Cit., hlm. 113.
} 
Namun jika kedua akad itu terpisah (tidak tergantung, muallaq) hukumnya boleh.Larangan kedua yaitu penghimpunan dua akad jual beli dalam satu akad jual beli didasarkan pada hadist Nabi Muhammad yang artinya: "Dari Abu Hurairah, "Rasulullah melarang jual beli dan pinjaman". (HR. Malik) Banyak tafsir tentang hadist ini, pendapat yang dipilih adalah pendapat yang mengatakan bahwa akad demikian menimbulkan ketidakjelasan harga dan menjerumuskan ke riba.

Misalnya seorang penjual berkata kepada orang banyak di sebuah jamaah, "Saudara-saudara, saya menjual barang ini seharga satu juta rupiah, jika dibayar tunai, dan satu juta dua ratus ribu rupiah jika cicilan setahun". Lalu seorang yang hadir berkata, "Saya beli". Disini telah terjadi ijab dan kabul, sementara harganya tidak jelas, karena dipilihkan dua macam harga. 164 Penafsiran lain, seseorang menjual suatu barang dengan cicilan, dengan syarat pembeli harus menjual kembali kepada orang yang menjual itu dengan harga lebih rendah secara kontan. Akad al-'Inah seperti ini merupakan hilah dari riba. Inilah yang disebut bay' al'Inah. Menurut Ibnu Qayyim, penafsiran inilah yang paling kuat.

\section{Take Over Pembiayaan Perbankan Syariah}

Menurut Al-Imrani, hybrid contracts ada lima macam, salah satunya yaitu akad-akad yang berbeda (al-'uqud almukhtalifah). Yang dimaksud dengan multiakad mukhtalifah adalah terhimpunnya dua akad atau lebih yang memiliki perbedaan semua akibat hukum di antara kedua akad itu atau sebagiannya. Seperti perbedaan akibat hukum dalam akad jual beli dan sewa, dalam akad sewa diharuskan ada ketentuan waktu, sedangkan dalam jual beli sebaliknya Hybrid contracts yang akadakadnya tidak bercampur dan tidak melahirkan nama akad baru tetapi nama akad dasarnya tetap ada dan eksis bahkan cenderung terpisah.

Hybrid ini dipraktikkan dalam suatu transaksi take over pembiayaan dari perbankan konvensional ke perbankan syariah. Pengaturan mengenai pengalihan utang ini pun telah dibuatkan fatwa oleh Majelis Ulama Indonesia, adapun fatwa tersebut yaitu Fatwa Dewan Syari'ah Nasional Nomor 31 Tahun 2002 Tentang Pengalihan Utang. Pertimbangan dibuatnya fatwa mengenai pengalihan utang adalah membantu masyarakat untuk mengalihkan utangnya dari non-syari'ah yang telah berjalan menjadi transaksi yang sesuai dengan prinsip syari'ah. Lembaga Keuangan Syari'ah perlu merespon kebutuhan masyarakat dalam berbagai produk inovasinya melalui akad pengalihan utang oleh Lembaga Keuangan Syari'ah. Agar praktik pengalihan utang dapat berjalan sesuai prinsip syari'ah, Dewan Syari'ah Nasional merasa perlu untuk menetapkan fatwa mengenai pengalihan utang.

Pengalihan utang dalam Fatwa DSN Nomor 31/DSN-MUI/VI/2002 Tentang Pengalihan Utang adalah pemindahan utang nasabah dari bank/lembaga keuangan konvensional ke bank/lembaga 
keuangan syariah. Nasabah adalah (calon) nasabah LKS yang mempunyai kredit (utang) kepada Lembaga Keuangan Konvensional (LKK) untuk pembelian asset, yang ingin mengalihkan utangnya ke LKS. Adapun terdapat empat alternatif yang dapat digunakan dalam pengalihan utang ini menurut Fatwa DSN MUI. Salah satu alternatif pengalihan utang yaitu LKS membeli sebagian aset nasabah, dengan seizin LKK, sehingga dengan demikian terjadilah syirkah al-milk antara LKS dan nasabah terhadap aset tersebut. Bagian asset yang dibeli oleh LKS adalah bagian asset yang senilai dengan hutang (sisa cicilan) nasabah kepada LKK. LKS menjual secara murabahah bagian asset yang menjadi miliknya tersebut kepada nasabah, dengan pembayaran secara cicilan.

\section{Pembiayaan dengan Akad Murabahah}

Akad murabahah merupakan transaksi pembiayaan jual beli barang, karena adanya pemesanan nasabah kepada bank dimana bank menyebut jumlah keuntungannya dan memberitahukan modal pembeliannya. Dalam murabahah tersebut bank memenuhi permintaan nasabah, untuk membeli suatu barang, dimana bank membelikan kebutuhan barang nasabah (investasi/modal kerja). Selanjutnya bank menjual kembali kepada nasabah ditambah dengan keuntungan yang disepakati. Cara pembayaran murabahah saat ini biasanya secara cicilan. Murabahah itu berasal dari kata ribhu (keuntungan dua pihak), artinya besarnya keuntungan harus disepakati kedua belah pihak. Jika bank tidak memberitahukan berapa pembeliannya, maka jual beli tersebut bukan jual beli murabahah. Kedua pihak harus juga menyepakati jangka waktu pembayaran. Harga jual dicantumkan dalam akad dan jika telah disepakati tidak dapat berubah selama berlakunya akad.

Dalam perbankan, murabahah lazimnya dilakukan dengan cara pembayaran cicilan. Dalam transaksi ini barang diserahkan segera setelah akad sedangkan pembayaran dilakukan secara tangguh. Namundalam praktiknya, bank sering kali mewakilkan kepada nasabah untuk membeli sendiri barang yang dia butuhkan, sehingga akad pembiayaan dilakukan dihadapan notaris, sebelum dana ditransfer dari bank kepada pihak penjual.

Hybrid Contracts pada Take Over Pembiayaan Hunian Syariah

\section{di Perbankan Syariah dalam Perspektif Hukum Ekonomi Islam}

Bank syariah saat ini sedang melambung popularitasnya. Selain daripada sistem bagi hasil yang menjadi daya tariknya, manusia sudah mulai mengetahui bahwa bunga atau riba yang diberikan oleh bank konvensional tidak dihalalkan oleh Allah dalam perspektif Hukum Islam. Pembiayaan hunian yang ditawarkan oleh berbagai bank kadang menjadi jalan keluar bagi orang-orang yang menginginkan sebuah hunian dengan cara mencicil ke bank yang memberikan fasilitas pembiayaan hunian tersebut. 
Bank syariah pun mulai mengembangkan fasilitasnya hingga kepada pembiayaan hunian syariah. Salah satu strategi pemasaran yang dikembangkan oleh bank-bank saat ini adalah dengan pengalihan (take over) pembiayaan hunian syariah. Take over pembiayaan hunian adalah pemindahan fasilitas pembiayaan yang berjalan disuatu bank ke pembiayaan bank lain. Pengambilalihan ini hanya untuk sisa pokok pinjaman nasabah dari bank pemberi pembiayaan pertama, yang dilanjutkan dengan mencicil sisa pokok pinjaman ke bank yang mengambilalih pembiayaannya.

Dalam bisnis perbankan, take over (pengalihan) utang dapat terjadi dari satu bank ke bank lain, baik dari sesama bank konvensional, dari bank konvensional ke bank syariah atau sebaliknya, maupun dari sesama bank syariah. Permintaan take over sepenuhnya berada di tangan nasabah. Nasabah berhak untuk memindahkan kreditnya ke bank lain yang dirasanya menguntungkan atau mungkin sesuai dengan prinsip yang diyakininya. Bank asal tidak berhak untuk melarang nasabah yang akan memindahkan kreditnya ke bank lain.

Produk pembiayaan yang diberikan oleh Bank Syariah Mandiri kepada nasabahnya dalam Pembiayaan Griya Bank Syariah Mandiri menggunakan akad ba'i murabahah. Akad ba'i murabahah dalam perspektif hukum Islam merupakan gabungan dari dua akad yaitu akad ba'i dan juga akad murabahah. Jadi, produk pembiayaan Griya Bank Syariah Mandiri mengandung multi akad atau hybrid
contracts.Proses take over yang dilakukan oleh Bank Syariah Mandiri sebagai Lembaga Keuangan Syariah kepada Lembaga Keuangan Konvensional dilakukan dengan syirkah al-milk.

Proses awal terjadinya take over yaitu permintaan nasabah untuk mengalihkan pembiayaan huniannya dari bank konvensional kepada bank syariah. Lalu Bank Syariah Mandiri melunasi sisa utang dari nasabah yang melakukan kredit rumah di bank konvensional. Setelah transaksi jual beli antara LKS dengan LKK selesai, lalu LKS membuat perjanjian akad jual beli dengan nasabah. Jual beli antara nasabah dengan Bank Syariah Mandiri dalam hal Pembiayaan Griya Bank Syariah Mandiri dilakukan menggunakan akad ba'i murabahah. Objek yang di akad-kan berupa rumah yang sisa kreditnya telah dibayarkan oleh LKS kepada LKK. Adapun modal dan keuntungan yang sudah dikeluarkan dan akan didapatkan oleh Bank Syariah Mandiri telah dibicarakan di awal perjanjian. Nasabah lalu harus membayar cicilan sisa utang kreditnya kepada Bank Syariah Mandiri. Take over yang dilakukan dalam Pembiayaan Griya Bank Syariah Mandiri telah sesuai dengan Fatwa Dewan Syari'ah Nasional Nomor 31/DSN-MUI/VI/2002 Tentang Pengalihan Utang.

Alternatif kedua dalam hal pengalihan utang yaitu LKS membeli sebagian aset nasabah, dengan seizin LKK, sehingga dengan demikian terjadilah syirkah al-milk antara LKS dan nasabah terhadap aset tersebut. Bagian asset yang dibeli oleh LKS adalah bagian asset yang senilai 
dengan hutang (sisa cicilan) nasabah kepada LKK. LKS menjual secara murabahah bagian asset yang menjadi miliknya tersebut kepada nasabah, dengan pembayaran secara cicilan. Alternatif kedua ini yang digunakan oleh Bank Syariah Mandiri dalam Pembiayaan Griya Bank Syariah Mandiri.

Take over pembiayaan hunian syariah memakan proses yang panjang dan juga menggunakan banyak akad. Apabila merujuk pada konsep hybrid contracts yang dilarang dalam perspektif Hukum Islam menurut beberapa ahli fikih, pembiayaan hunian syariah ini juga termasuk kedalam nya. Tetapi apabila dilihat dari akad-akad yang digunakan yaitu gabungan dari akad ba'i dan juga akad murabahah, menurut pandangan ahli fikih kontemporer, penggabungan akad ini tidak termasuk dalam hybrid contracts yang dilarang dalam Hukum Islam.

Tiga buah hadits Nabi Muhammad SAW yang menunjukkan larangan penggunaan hybrid contracts. Ketiga hadits itu berisi tiga larangan, pertama larangan menggabungkan bay' dan salaf, kedua, larangan bai'ataini fi bai'atin, dan ketiga larangan shafqataini fi shafqatin. Ketiga hadits itulah yang selalu dijadikan rujukan para ahli syariah, konsultan, dan banker syariah tentang larangan akad two in one dalam satu transaksi. Namun harus dicatat, larangan itu hanya apabila akad two in one yang mengandung riba dan gharar.

Bahkan menurut Ibnu Qayyim hanya pada akad yang mengandung riba. Dengan demikian, apabila dua akad atau tiga akad dalam satu transaksi dibolehkan sepanjang tidak mengandung riba. Karena itu larangan dua akad dalam satu transaksi tidak bisa digeneralisasi.168 Begitupula dengan akad mengenai pembiayaan hunian syariah oleh Bank Syariah Mandiri. Proses take over dilakukan tanpa adanya riba dan gharar karena telah diberitahukan sebelumnya mengenai modal dan keuntungan bagi hasil yang akan didapatkan oleh Bank Syariah Mandiri juga nasabah. Jadi, larangan multi akad atau hybrid contracts yang berkembang selama ini ditafsirkan secara sempit dan salah. Larangan tersebut berakibat pada terhambatnya pengembangan inovasi produk perbankan syariah di Indonesia.

Termasuk di dalamnya proses take over pembiayaan hunian syariah yang mengandung multi akad. Simpulan dari penelitian ini bahwa proses take over yang dilakukan oleh Bank Syariah Mandiri ke Lembaga Keuangan Konvensional dengan sistem syirkah al-milk, lalu memberikan produk pembiayaan hunian syariah kepada nasabah dengan akad ba'i murabahah tidak dapat dimasukkan ke dalam hybrid contracts yang dilarang dalam perspektif Hukum Islam. 


\section{DAFTAR PUSTAKA}

Agustianto Mingka. Reaktualisasi dan Kontekstualisasi Fikih Muamalah Ke-Indonesiaan Upaya Inovasi Produk Perbankan dan Keuangan Syariah. Jakarta: Iqtishad Publishing, 2014.

Ascarya. Akad E Produk Bank Syariah. Jakarta: Raja Grafindo Persada, 2007.

Bank Syariah Mandiri. Pembiayaan Griya BSM. https://www.syariahmandiri.co.id/category/ consumer-banking/pembiayaan-konsumer/pembiayaan-griya-bsm/

Djemabut Blaang. Perumahan dan Permukiman Sebagai Kebutuhan Pokok. Jakarta: Yayasan Obor Indonesia, 1986.

Muhammad Syafi'i. Bank Syariah Suatu Pengenalan Umum. Bogor: Tazkia Institute, 2000.

Munawwir. Kamus Al-Munawwir Arab-Indonesia. Surabaya: Pustaka Progresif, 1997.

Syamsul Anwar. Hukum Perjanjian Syariah "Studi Tentang Teori Akad Dalam Fikih Muamalat". Jakarta: Raja Grafindo Persada, 2007.

Undang-Undang Nomor 1 Tahun 2011 Tentang Perumahan dan Kawasan Permukiman.

Undang-Undang Nomor 21 Tahun 2008 Tentang PerbankanSyariah Urip Santoso. Hukum Perumahan. Jakart: Kencana, 2014. 